\title{
Integration of Medical Physical Principles with Empathy as Scientific Strengthening and Counseling Action
}

\author{
Henny Indreswari ${ }^{1}$, Nugraheni Warih Utami $^{2}$, Riskiyana Prihatiningsi ${ }^{3 *}$, Rizka Apriani ${ }^{4}$ \\ ${ }^{1234}$ Universitas Negeri Malang \\ *Corresponding author, e-mail: riskiyana.prihatiningsih.fip@um.ac.id
}

Received May 30, 2021;

Revised May 31, 2021;

Accepted June 02, 2021;

Published Online 2021-06-03

\section{Conflict of Interest}

\section{Disclosures:}

The authors declare that they have no significant competing financial, professional or personal interests that might have influenced the performance or presentation of the work described in this manuscript.

\begin{abstract}
This study aims to see a picture of empathy by integrating biological, sociological and psychological by using a delayed broadcast application which is intended to help Guidance and Counseling students to increase empathy and communication skills through a biopsychosocial approach to identify counselee problems. The implementation study uses a formative evaluation framework to see the counselor's communication with the counselee through three stages; 1) evaluation, consisting of a conceptual review; 2) technical, both formal and informal by the lecturer; 3) evaluation of Guidance and Counseling students who are involved in surveys and observations. The findings of this study indicate that bio-psycho-social video delays can improve counseling communication techniques (empathy) for prospective counselors. The results of this study can be used as a reference for lecturers and prospective counselors in providing learning about the counseling process so as to improve the quality of prospective counselors, especially in increasing empathy which is one of the counselor's character competencies.
\end{abstract}

Keywords: Delayed Broadcast, Biopsychosocial, Formative Evaluation, Empathy, Basic Communication Counseling

\section{Introduction}

Biopsychosocial (biopsychosocial approach) is a model approach that can be used in the process of providing services to counselees. Biopsychosocial emphasizes the interactive influence of a combination of biological, psychological and social elements on the development of problems experienced by the counselee (Mayangsari, 2018). This model seeks to find a combination of body or physical combinations, emotions, and also pays attention to social (external) integration by making these components into a unified system that is interconnected with each other. 
The Biopsychosocial Model has actually been known in the counseling world. The implementation of counseling by the counselor to the counselee certainly cannot be separated by biological, psychological and social systems (Sarafino and Smith, 2014). However, in reality the combination of these systems still cannot be used optimally and it can be said that the services carried out by counselors are still not optimal. It is known that the reality in the field is that there are still many counselors who have not explored biological, psychological, or social systems. Where the three systems have continuity with each other. The description of each of these systems will be explained as follows.

Empathy in the learning of Guidance and Counseling students requires strengthening. Empathy has been recognized as the cornerstone of a highly specialized relationship (Aggarwal and Guanci, 2014). Research in particular finds that prospective counselors often begin their activities with idealism, so a number of studies have found a decrease in empathy in the latter part of the education period (Hojat et al., 2009). There are many strategies to teach empathy to students. This strategy addresses various aspects of empathy-emotive, moral, cognitive, and behavioral learning carried out with interpersonal skills, audio and video recordings. In the study, improvements did not create a lasting impact on counselor skills.

The condition of prospective counselors is also not much different from counselors who have served in the field of education (schools). The data obtained that prospective counselors are also observed through their behavior which shows a tendency to have low empathy. (Hidayah, 2010) conducted a study on BK S1 students in 2006, regarding the implementation of the BK curriculum that was in effect at that time, the content of the cognitive aspects seemed larger than the attitudes, values and psychomotor aspects, the proportions of which seemed lower; affective learning (empathy, respect for diversity, personal intelligence) through design, does not get a sufficient portion. This condition is one of the reasons for reviewing the act of learning in the context of preparing counselors, which is oriented to affective aspects which are the counselor's "core conditions", such as genuineness or congruence, unconditional positive regard, and empathy (Indreswari, 2016).

Prospective counselors require complex knowledge (Dodd, 2020). Identifying clients' problems in clinical interviews is a complex skill. Too often counselors ignore biological aspects (face pain, fatigue, pain, etc.), and social factors, which may only pay attention to the psychological realm. Though overall contribute to the counselee's problems. Empathy in the communication process with the counselee, generally aims to remind students who must consider all aspects of the counselee's history and integrate it through a biopsychosocial approach. The second aspect of the clinical interview, or the process of interpersonal interaction, is the implementation of the microskills of communication skills used by the participants. Microskills refers to interview strategies used to help facilitate successful interviews and to establish a relationship between the interviewer in this case is the counselor and the interviewee (counselee). Microskills can be realized in verbal and nonverbal forms (Maristy, 2020). Verbal strategies include using different types of questions (open and closed), reflecting paraphrasing, minimal encouragers and using different tones of voice. Nonverbal strategies include facial expressions, gestures and postures, as well as encouragers such as nodding and eye contact. A counselor who is skilled at listening to verbal responses and observing the counselee's nonverbal responses will be able to monitor how comfortable the counselee's condition is, and this condition will bring the counselor to adjust the counseling interview process he is doing.

Development research that has been carried out in the context of Guidance and Counseling has not been maximized. Development research has not led to the strengthening of detailed actions, educational contexts and instructional design of the multimedia package of counseling education, communication with counselees, and reporting of formative evaluations. Therefore, the author tries to examine the integration of Medical Physical Principles with Empathy as Scientific Reinforcement and Counseling Action.

\section{Method}

This study uses an evaluative research design with a quantitative-descriptive approach. Important aspects of the study and evaluation are 1) learning design and 2) critical reflection by students. Boud, Keogh and Walker (1985: 19) define reflection as "intellectual and affective activities in which individuals engage to explore their experiences in order to construct new understanding and appreciation processes". Schon (1983: 54-55) describes reflection in action as analogous to solving authentic problems that occur in the real world. This reflects the process more than a post-mortem. The evaluation program is carried out in order to maintain the quality and as a guarantee of the quality of education. This is done to examine more deeply the increasing 
number of educational technology packages developed in the Guidance and Counseling Department, Faculty of Education - State University of Malang. The overall focus of this program is on learning design through delayed broadcast technology which may be better if it has student support. The key elements of evaluation are as follows. 1. The evaluation takes place from the initial stage in the development of the delayed broadcast technology program through a biopsychosocial approach. 2 . The evaluation and study consider three different evaluation domains. The evaluation domain includes 1) instructional; 2) conceptual design, interface; and 3) display design that has an influencing nature. 3. Internal and external evaluations from learning materials (content) experts, instructional designers, graphic designers, student users and educational evaluators. Using a variety of data collection techniques including questionnaires, checklists, focus groups, observations and expert reviews.

As for the description analysis carried out by the researcher, the process will be assisted with SPSS software.

\section{Results and Discussion}

\section{Result}

\section{A. Differences in Basic Communication Skills Counseling (Empathy) Students Before and After Interventions are given (delayed video).}

This research begins by making an instrument in the form of a questionnaire consisting of 60 statement items. The instrument was tested and tested by 2 experts. Based on the results of the expert test by 2 experts, the statements in the bio-psycho-social questionnaire were revised and reduced to 28 statement items. The final result of this questionnaire was uploaded to the google form and the google drive link was distributed to 100 students of the Guidance and Counseling Department of FIP UM. Then, the researcher made a delayed video about the basic skills of counseling communication (empathy). The video was given to 100 students who had filled out the initial questionnaire, this was an intervention carried out by researchers to improve the basic skills of counseling communication (empathy). After the students watched the video, they were asked to fill in the answers to questions by the researchers which were used as process evaluations, then they filled out the questionnaire again with the aim of seeing the differences in basic counseling skills (empathy) before watching the video and before watching the video.

The differences in basic counseling communication skills (empathy) for Guidance and Counseling students before and after being given an intervention by watching delayed videos can be seen in Table 1.1. and Table 1.2.

Tabel 1.1 Paired Samples Statistics

\begin{tabular}{rrrrrr}
\hline & & Mean & N & Std. Deviation & Std. Error Mean \\
Pair 1 & Post & 72,63 & 100 & 9,636 &, 964 \\
& Pre & 67,62 & 100 & 13,310 & 1,331 \\
\hline
\end{tabular}

Based on Table 1.1. in the Mean column shows the average score of basic communication skills in counseling students of the Guidance and Counseling Department of FIP UM before and after being given a video delay. For the average score of basic counseling communication skills (empathy) students of the Guidance and Counseling Department of FIP UM after being given a delayed video broadcast of 72.63, and the average score of basic counseling communication skills (empathy) students of the Guidance and Counseling Department of FIP UM before being given delayed video showing 67.62. Column N shows the number of paired data of 100 each. Column Std. Deviation shows the coefficient of standard deviation or standard deviation, which is 9.636 for the score of basic skills of counseling communication (empathy) for Guidance and Counseling Department of FIP UM students after being given a video delay, and 13,310 for 
the score of basic skills of counseling communication (empathy) for Guidance and Counseling Department students. FIP UM counseling before being given a video delay. Std. Error Mean is the magnitude of the error coefficient of the mean used to estimate the size of the population mean estimated from the sample. From the value of the Standard Error Mean, the average population score can be estimated. The magnitude of the Std Error Mean for the score of basic counseling communication skills (empathy) for Guidance and Counseling FIP UM students after being given a delayed video broadcast was 0.964 , and for a counseling communication basic skill score (empathy) students of the Guidance and Counseling Department of FIP $\mathrm{UM}$ before being given a video delay broadcast. of 1.331 .

Tabel 1.2 Paired Samples Test

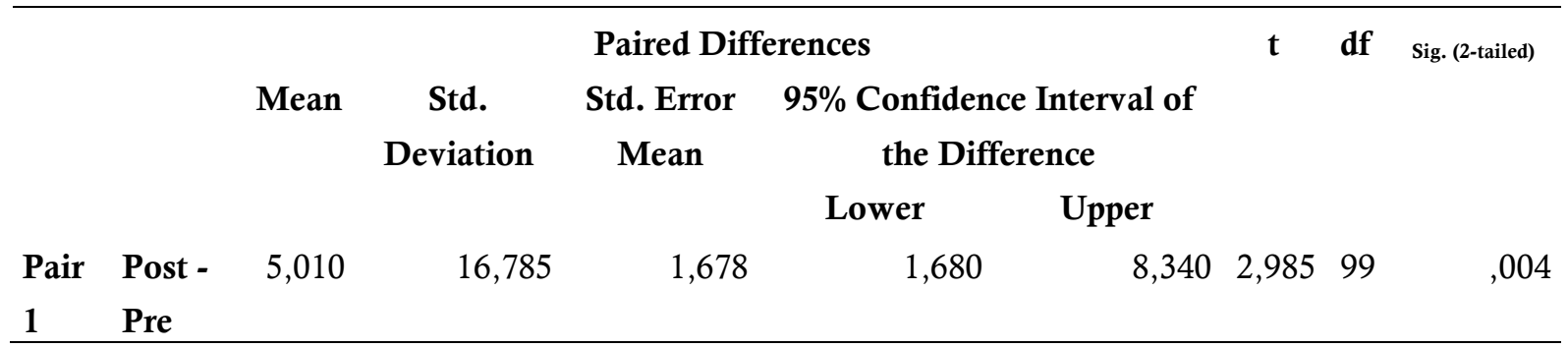

Based on Table 1.2 to determine the acceptance or rejection of H0. In the Mean column is the coefficient of the average difference between the basic skills of counseling communication (empathy) students of the Guidance and Counseling Department of FIP UM before and after being given the intervention of watching delayed videos, which is 5.010. This value is the difference between the average score of basic counseling communication skills (empathy) of Guidance and Counseling Department FIP UM students after being given a video delay and the average score of counseling communication basic skills (empathy) students of Guidance and Counseling Department FIP UM before being given the video. delay $(72.63-67.62=$ 5.010). Column $t$ shows the magnitude of the calculated $t$ coefficient of 2,985 with a P-value coefficient of 0.04. To state whether the average difference is significant by looking at the P-value coefficient and comparing it with a significance level of 0.05 . Based on the results of the analysis, the $\mathrm{P}$-value coefficient of 0.04 and smaller than 0.05 , it is stated that there is a significant difference in the basic skills of counseling communication (empathy) for Guidance and Counseling Department of FIP UM students before and after being given delayed video. To determine whether the provision of delayed video shows an impact on improving the basic skills of counseling communication (empathy), it is done by comparing the average value. The average value of basic counseling communication skills (empathy) before being given delayed video is 67.62, and the average value of counseling communication basic skills (empathy) after being given delayed video is 72.63 , it can be concluded that giving delayed video have an impact on improving the basic skills of counseling communication (empathy).

\section{B. Formative Evaluation of Delayed Video Shows for Guidance and Counseling Department Students, FIP UM to Improve Basic Counseling Communication Skills (Empathy)}

The researcher gave a delayed video to students of the Guidance and Counseling Department of FIP UM by providing them with a video link. Then, they were given a bio-psycho-social questionnaire as well as a process evaluation consisting of 5 questions. Based on the results of the answer analysis from the Guidance and Counseling Department students, FIP UM is a delayed video showing explanations and examples of counseling related to basic counseling skills (empathy) as a whole very helpful to improve their understanding of the bio-psyo-social aspects that will be discussed. used in counselling.

There were several answers from students, namely "I have become increasingly aware that it is not only the counselee's words that are the focus when we do counseling, but also the movements and intrinsic words are also very important to pay attention to in order to really know the counselee's condition and not get the wrong target in giving service". The next answer "By watching the video I learned more by understanding excessive body movements or facial expressions that change according to the counselee's feelings". Then, the 
students' answers to the second question regarding the extent to which the video helped improve their observation skills during the counseling process were that overall they were very helpful and made it easier to identify the aspects that have been explained, because the video presented provides examples of the counseling process in very detail and in accordance with the aspects to be conveyed by the presenter, making it very easy for the audience when observing the counseling process. The third question of the process evaluation is about the extent to which bio-psycho-social videos provide benefits for improving students' abilities and skills in implementing counseling.

Their answer is that the video provides many benefits to them because the video contains how to build a relationship with the counselee, create a sense of security and comfort because it is kept confidential, understand and share what the counselee is feeling, emphasize and sort out the focus of the problem. , the implementation is carried out according to the duration of the initial agreement, several meetings are held to achieve optimal counseling and end with the counselee being aware of and understanding the problem and understanding what must be done.

The final question of the process evaluation is about the extent to which bio-psycho-social instruments can help students identify their abilities and skills in implementing counseling. Overall, their answer is that the bio-psycho-social instrument really helps them in recognizing their abilities and skills in implementing counseling, by using this instrument they can clearly see how the counselee's condition is during the counseling process in video shows.

\section{Discussion}

Biopsychosocial has the view that internally individuals have internal conditions consisting of biological systems and psychological systems that interact and are related, and also at the same time these internal conditions are related to social systems or external conditions outside the individual. Every system, both internal and external, is related to each other and cannot be separated, so to understand individual behavior and provide appropriate interventions, counselors need to understand well the systems that exist in individuals as their main work domain (Sarafino and Smith, 2007). 2014). Empathy is an important thing to be trained by counselors or prospective counselors. Empathy is knowing the feelings and feelings experienced by others. This knowledge and understanding makes the glue of relationships in relationships in establishing a social relationship, as well as when conducting counseling sessions (Goleman and Boyatzis, 2017).

The counselor's empathy attitude has an influence on students' interest in implementing counseling services (Fitria, 2011). Empathy is built from several aspects, namely affective and cognitive components. The affective component relates to all forms of feelings towards other people. Various emotional responses also become attributes of the affective component in empathy, so empathy can sometimes also be referred to as affective resonance, namely emotional exchange (Fourie, Subramoney and Gobodo-Madikizela, 2017). This research was conducted using a delayed video which was addressed to prospective counselors, namely Guidance and Counseling Department students. The average score of counseling communication basic skills (empathy) for Guidance and Counseling Department students after being given a delayed video showing was 72.63, and the average score for counseling communication basic skills (empathy) for Guidance and Counseling Department students before being given a delayed video showing was 67,62 .

Based on the results of the analysis obtained a P-value coefficient of 0.04 and smaller than 0.05 , it is stated that there is a significant difference in the basic skills of counseling communication (empathy) students of the Guidance and Counseling Department before and after being given a delayed video. The increase in the value of empathy after seeing the delayed broadcast of the counseling session is an indication that there is learning that occurs after watching the delayed broadcast. Increasing the value of empathy in prospective counselors becomes important later as a counselor when carrying out counseling sessions. Empathy is one of the techniques that is widely used during counseling sessions, this technique is believed to provide an increase in the positive impact of counseling for recipients of counseling services (Handari, 2016). The use of delayed broadcast videos as a direct example of a counseling session by paying attention to biological, psychological and social aspects with empathy as a main skill in the example of the counseling session becomes direct learning to be observed by prospective counselors directly. The process of observing and imitating the behavior and attitudes of others is an act of learning. When viewing the video, the cognitive aspect is delayed, which is the basis for the emergence of behavior that is in accordance with what has been observed, Bandura in (Slavin, 2008). Empathy is also related to a series of thinking patterns in taking the 
perspective of others who receive an empathetic response given (Zaki and Ochsner, 2012). The use of videos or films or by giving examples using films or videos has proven to be effective in increasing the empathy of prospective counselors (Sutanti, 2015; Auliyah and Flurentin, 2016).

Evaluation of the process after the video broadcast was delayed, got feedback from prospective counselors that, Body movements, facial expressions and expressions of the counselee must be responded to appropriately, with an empathetic attitude carried out by the counselor, the counseling process is going better. Empathy as the personality of the counselor as the main capital in establishing communication with the counselee and being able to feel what is felt by the counselor (Amalia, 2019)

\section{Conclusion}

Based on the results of the research that has been done, there are differences in the basic communication skills (empathy) of prospective counselors before and after watching delayed videos. This is evidenced by the t-count coefficient of 2.985 with a P-value coefficient of 0.04 . To state whether the average difference is significant by looking at the P-value coefficient and comparing it with a significance level of 0.05 . Based on the results of the analysis, the P-value coefficient of 0.04 and smaller than 0.05 , it is stated that there is a significant difference in the basic skills of counseling communication (empathy) for Guidance and Counseling Department of FIP UM students before and after being given delayed video.

The findings of this study indicate that bio-psycho-social video delays can improve counseling communication techniques (empathy) for prospective counselors. The results of this study can be used as a reference for lecturers and prospective counselors in providing learning about the counseling process so as to improve the quality of prospective counselors, especially in increasing empathy which is one of the counselor's character competencies.

\section{References}

Aggarwal, R. and Guanci, N. (2014) 'Teaching empathy during clerkship and residency', Academic Psychiatry, 38(4), pp. 506-508.

Amalia, R. (2019) 'EMPATI SEBAGAI DASAR KEPRIBADIAN KONSELOR', Jurnal Pendidikan dan Konseling (JPDK), 1(1), pp. 57-61.

Auliyah, A. and Flurentin, E. (2016) 'Efektifitas Penggunaan Media Film untuk Meningkatkan Empati Siswa Kelas VII SMP', Jurnal Kajian Bimbingan dan Konseling, 1(1), pp. 19-26.

Dodd, A., Guerin, S., Delaney, S., \& Dodd, P. (2020). Complicated grief knowledge, attitudes, skills, and training among mental health professionals: a qualitative exploration. Death studies, 1-12.

Fitria, R. (2011) 'Hubungan antara Persepsi Siswa tentang Kemampuan Empati Konselor dengan Minat Siswa Terhadap Layanan Konseling Perorangan pada Siswa kelas VIII di SMP Negeri 7 Semarang Tahun Ajaran 2009/2010'. UNNES.

Fourie, M. M., Subramoney, S. and Gobodo-Madikizela, P. (2017) 'A less attractive feature of empathy: intergroup empathy bias', Empathy: an evidencebased interdisciplinary perspective. INTECH (London), pp. 45-61.

Goleman, D. and Boyatzis, R. (2017) 'Emotional intelligence has 12 elements. Which do you need to work on', Harvard Business Review.

Handari, S. (2016) 'Empati Sebagai Pengembangan Seni Konseling Untuk Efektivitas Pelayanan Konseling', Lentera, 18(1).

Hidayah, N. (2010) 'Process-Audit Dalam Penyelenggaraan Pendidikan Akademik Jenjang S-1 Bimbingan Dan Konseling', Jurnal Pendidikan dan Pembelajaran (JPP).

Hojat, M. et al. (2009) 'The devil is in the third year: a longitudinal study of erosion of empathy in medical school', Academic Medicine, 84(9), pp. 1182-1191.

Indreswari, H. (2016) 'Keefektifan model kemitraan dalam belajar untuk meningkatkan kemampuan empati calon konselor'. Universitas Negeri Malang.

Maristy, H. S. (2020, August). Contextualization to Enhance Students' Writing Ability. In 1st International Conference on Language, Literature, and Arts Education (ICLLAE 2019) (pp. 196-202). Atlantis Press. 
Mayangsari. (2018) 'Penggunaan Tools Assesment Biopsikososial dan Spiritual Anak yang menjadi Korban Perceraian Orang Tua', EMPATI: Jurnal Ilmu Kesejahteraan Sosial. doi: 10.15408/empati.v7i1.10002.

Sarafino, E. P. and Smith, T. W. (2014) Health psychology: Biopsychosocial interactions. John Wiley \& Sons.

Slavin, R. E. (2008) 'Psikologi Pendidikan: Teori dan Praktik, terj', Marianto Samosir. Jakarta: Indeks.

Sutanti, T. (2015) 'Efektivitas Teknik Modeling untuk Meningkatkan Empati Mahasiswa Prodi BK Universitas Ahmad Dahlan', Jurnal Psikologi Pendidikan dan Konseling: Jurnal Kajian Psikologi Pendidikan dan Bimbingan Konseling, 1(2), pp. 188-198.

Zaki, J. and Ochsner, K. N. (2012) 'The neuroscience of empathy: progress, pitfalls and promise', Nature neuroscience, 15(5), pp. 675-680.

Article Information (Supplementary)

Conflict of Interest Disclosures:

The authors declare that they have no significant competing financial, professional or personal interests that might have influenced the performance or presentation of the work described in this manuscript.

Copyrights Holder: <indreswari $><2021>$

First Publication Right: BISMA The Journal of Counseling

https://doi.org/10.xxxx/ $x \times x \times x$

Open Access Article | CC-BY Creative Commons Attribution 4.0 International License.

@creative

Word Count: 